Protestantismo em Revista é licenciada sob uma Licença Creative Commons.

http://dx.doi.org/10.22351/nepp.v44i2.3710

\title{
Ensino Religioso na educação brasileira e os marcos legais: prerrogativas e impasses
}

\author{
Religious Education in Brazilian education and the legal landmarks: prerrogatives and \\ impasses
}

\author{
Sandra Célia C. G. da Silva* \\ Ivonete Barreto de Amorim ** \\ Sueli Mota R. de Souza $a^{* * *}$
}

\begin{abstract}
Resumo
O presente artigo tem por objetivo apresentar o tema proposto pautado numa concepção interdisciplinar, explicitando algumas questões acerca do ensino religioso na educação brasileira, referendados nos marcos legais que discutem preconceitos, prerrogativas e impasses sobre essa temática que na atualidade se apresenta como questão decisória no rumo para escolas públicas no que concerne ao ensino religioso. Tendo como aporte metodológico a revisão de literatura, os marcos legais que subsidiam a legislação brasileira e a proposição apresentada pelo Fórum Nacional Permanente de Ensino Religioso (FONAPER) conclui-se que o Ensino Religioso na educação brasileira, com todas as suas prerrogativas e impasses ainda é motivo de muitas discussões e controvérsias. A permanência da disciplina no currículo acentua ainda mais esta polêmica e referenda toda a tessitura da discussão exposta neste estudo e deixa um chamado para novas reflexões.
\end{abstract}

[Texto recebido em janeiro de 2018 e aceito em janeiro de 2018, com base na avaliação cega por pares realizada por pareceristas ad hoc]

* Bacharel e Licenciada em Ciências Sociais (UNIVALE). Pós-Graduada em Sociologia (UFMG). Mestra em Ciências da Religião (PUC/GO). Doutora em Ciências da Religião (PUC/GO). Realiza estágio PósDoutoral em Educação (PPGEdu/UNEB). Professora Adjunta no Departamento de Educação - Campus XII - Guanambi - da Universidade do Estado da Bahia (UNEB). Membro da Associação de Cientistas Sociais da Religião do Mercosul (ACSRM). Conselheira da Regional Centro-Oeste da Sociedade de Teólogos e Cientistas da Religião (SOTER). Líder do Grupo de Estudos e Pesquisas em Educação, Religião, Cultura e Saúde (GEPERCS). E-mail: sandraccgs@hotmail.com

** Licenciada em Pedagogia. Especialista em Avaliação e em Educação Infantil. Mestre em Educação e Contemporaneidade. Doutora em Família na Sociedade Contemporânea. Pós-Doutoranda em Educação e Contemporaneidade (PPGEduC/UNEB). Líder do Grupo de pesquisa EPODS. Professora Adjunta da Universidade do Estado da Bahia/Campus XI, Serrinha, Bahia - Brasil. E-mail: ivoneteeducadora@hotmail.com

*** Graduada em Ciências Sociais (UFBA). Mestra em Sociologia (UFBA). Doutora em Ciências Sociais (UFBA). Realizou estágio de Pós-Doutorado na Università degli Studi di Firenze. Professora Titular no Departamento de Educação e no Programa de Pós-Graduação em Educação e Contemporaneidade da Universidade do Estado da Bahia (UNEB). Pesquisadora no campo das Ciências Sociais e Educação, com ênfase nos temas Educação, Saúde e Religião. E-mail: sumota.uneb@gmail.com 


\title{
Palavras-chave
}

Ensino Religioso. Educação Brasileira. Marcos Legais.

\begin{abstract}
The goal of this article is to present the proposed theme guided within an interdisciplinary conception, explaining some of the issues of religious education in Brazilian education, referenced in the legal landmarks which discuss prejudices, prerogatives and impasses on this theme which, in current times, is presented as a deciding issue in the path for public schools with regard to religious education. Having as methodological support the review of literature, the legal landmarks which provide support for the Brazilian legislation and the proposal presented by the Forum Nacional Permanente de Ensino Religioso (FONAPER) [Permanent National Forum of Religious Education] one concludes that Religious Education in Brazilian education, with all of its prerogative and impasses, still is motive for many discussions and controversies. The permanence of the discipline in the curriculum accentuates this polemic even more and references the whole weaving of the discussion presented in this study and leaves a call for new reflections..
\end{abstract}

\section{Keywords}

Religious Education. Brazilian Education. Legal Landmarks.

\section{Introdução}

Pensar uma produção que tece importantes reflexões acerca do ensino religioso na educação brasileira nos remete a acionar e mobilizar diferentes possibilidades sobre o âmbito da ciência da religião e no âmbito da educação, desvelando conceitos, marcos legais, preconceitos, prerrogativas e impasses sobre essa temática que na atualidade se apresenta como questão decisória no rumo para escolas públicas no que concerne ao ensino religioso.

Com efeito, o presente artigo tem por objetivo apresentar o tema proposto pautado numa concepção interdisciplinar, explicitando algumas questões acerca do ensino religioso na educação brasileira, referendados nos marcos legais que tanto têm indicado caminhos de avanços quanto de retrocessos sobre essas discussões.

O debate sobre o Ensino Religioso na Educação Brasileira perpassa momentos históricos do nosso país. Algo ainda pouco enfrentado e que passa por relações de poder, envolvendo disseminar, catequizar, disciplinar, doutrinar, reproduzir e conduzir valores condizentes à mesma crença de quem detém o mesmo. Entre idas e vindas, legislações e dúbias interpretações e discussões sobre esta temática, percebemos que ainda existem lacunas e instiga várias interpretações aguçando inúmeras inquietações. No entanto, trazemos aqui um olhar interdisciplinar, procurando desvelar alguns pontos que carecem de uma análise mais detida, dentre eles as suas prerrogativas, tendo em vista os impasses por que se tem passado esta discussão. 
Trazemos à luz uma discussão que tem como aporte metodológico uma revisão de literatura, perpassando por vários teóricos de diversas áreas do conhecimento, subsidiados pelos marcos legais existentes na legislação brasileira, coadunando com o debate e a proposição apresentada pelo Fórum Nacional Permanente de Ensino Religioso (FONAPER).

\section{A religião enquanto ciência: prerrogativas e impasses}

Há algum tempo o fenômeno religioso vem sendo objeto de estudo e de pesquisa na área das Ciências da Religião, nas mais variadas partes do mundo e nos contextos sociais diversificados. Os estudos das religiões ou do fenômeno religioso, em seus diferentes enfoques teóricos, apresentam as diversificadas tensões que a religião comporta, exigindo uma visão interdisciplinar procurando romper a superficialidade teórica.

O grande desafio nesse campo, na contemporaneidade brasileira, é compreender o fenômeno religioso como fundamental, para entender a diversidade cultural, exigindo uma melhor reflexão filosófica que dê conta da estrutura específica da atividade religiosa. Tendo como aporte teórico contribuições dos estudiosos, no que concerne à temática proposta, faremos uma reflexão conceitual da religião, como fenômeno científico que se destaca na atualidade, analisando-a a partir da concepção das prerrogativas e dos impasses.

Segundo Huff Júnior, não é possível repensar ou reescrever toda história religiosa do Brasil cada vez que se investiga a história do campo religioso, mas é preciso investigála devido às mudanças. ${ }^{1} \mathrm{O}$ espaço simbólico religioso é reconstruído e ressignificado em meio às relações sociais e políticas. A questão religiosa depende das estruturas vigentes e da cultura estabelecida.

A especificidade do campo religioso brasileiro está relacionada com a história do nosso país, de acordo com nosso próprio campo e de seus habitus religiosos. O campo religioso brasileiro apresenta dinâmicas e especificidades próprias. A importância do campo religioso brasileiro ocorre pela existência de bens simbólicos dentro da sua formação histórica. Para Huff Júnior,

[...] falar de religião é falar de tradição. Poder-se-ia nessa ótica, por exemplo, enquadrar o campo religioso brasileiro no campo de batalhas e de força de longuíssima duração que é o cristianismo enquanto religião que proporciona o material simbólico elementar e aglutinador da maioria das tradições religiosas locais. Importa, por exemplo, considerar além das

1 HUFF JUNIOR, Arnaldo E. Campo religioso brasileiro e a história do tempo presente. Cadernos CERU, série 2, v. 19, n. 2, dez. 2008. 
práticas, crenças e métodos, também as ideias sistematizadas em forma de dogma, ou seja, as teologias em questão. ${ }^{2}$

Na concepção de Sanchis, o campo religioso brasileiro é o espaço em que se manifestam crenças e tradições marcadas não só por oposições, mas também por analogias, complementaridades e sincretismos desenvolvidos à margem de instituições religiosas oficiais. ${ }^{3}$ Dentro dessa complexidade, o cristianismo católico não deixa de ser um ponto de referência genérico, em torno do qual se constroem as diversas identidades religiosas. O caráter mágico das religiões populares brasileiras não opera em seu estado puro, mas foi trabalhado e transformado lentamente pelo processo de modernização da sociedade brasileira.

O pluralismo religioso brasileiro é composto pela existência de um amplo espectro de religiões mágicas, onde os fiéis transitam. A diversidade religiosa brasileira torna-se um problema, segundo Montero, constituindo um perigo quando tratada de maneira geral. ${ }^{4}$ Pode ser analisada a partir do eixo de convergência entre religião e modernidade, como contraponto da tradição/razão, reduzindo o fenômeno religioso apenas a uma de suas dimensões:

Procurar compreender a sociedade brasileira pela fresta da tradição nos coloca de antemão diante de alguns modos já consagrados de equacionar a questão da religião, a questão da relação entre religião e modernidade, cujos pressupostos e desdobramentos gostaríamos de evitar. Um deles, mais geral, diz respeito à vinculação do processo de modernização à secularização da sociedade; outro, mais específico, se refere a uma tendência essencialista de compreender a cultura brasileira. ${ }^{5}$

No entanto, não são somente essas as características da religião que podem ser verificadas no campo religioso atual, também o reencantamento do mundo ou remagificação se apresenta como uma dimensão a ser considerada. Podemos entender o campo religioso brasileiro na atualidade à luz das afirmações de Parker, para quem,

No seio das mutações culturais, as religiões que não são indiferentes ao processo de modernização, portam valores e processos que ajudam a secularização, mas, ao mesmo tempo, oferecem elementos simbólicos que contribuem ao reencantamento do mundo, sendo especialmente notável a

2 HUFF JUNIOR, 2008, p. 56.

3 SANCHIS, Pierre. A religião dos Brasileiros: teoria e sociedade. Belo Horizonte: UFMG, 1999.

4 MONTERO, Paula. Magia, racionalidade e sujeitos políticos. 1994. Disponível em: <htttp://www.anpocs.org.br/portal/publicações/rbcs0026/rbcs2606.htm>. Acesso em: jun. 2017.

5 MONTERO, 1994. 
contribuição dos neoconservadorismo, dos fundamentalismos e dos neofundamentalismos. ${ }^{6}$

Afirma ainda o autor supracitado que um traço característico da modernidade religiosa é a pluralidade, onde a desinstitucionalização de alternativas religiosas e a desregulação do campo religioso causam vários fatores, uns de aspectos positivos e outros de aspectos negativos. ${ }^{7}$ Já Montero diz que as tradições religiosas estão em constante processo de reinvenção, reestruturação e rearticulação, transitando livremente em diversos cultos, articulando crenças e buscando adesões dentro de um vasto campo religioso. ${ }^{8}$

Para que possamos entender o campo epistemológico da religião enquanto ciência, trazemos em voga o conceito de religião. Segundo Lemos, a tentativa de alguns autores em conceituar religião evidencia a dificuldade de apresentá-la, de forma isolada de suas concepções mais gerais da sociedade. ${ }^{9}$ Para Croatto, o termo 'religião' tem sua origem no latim (religio) cuja etimologia "dá a idéia de atadura (re-ligare) do ser humano com Deus". Religião pode ser "entendida como um sistema de idéias e práticas pode-se falar de 'religiões' (no plural)". ${ }^{10}$

Para Durkheim, a religião se define como sendo um "sistema solidário de crenças e de práticas relativas a entidades sagradas, ou seja, separadas, interditas, crenças e práticas que unem em uma mesma comunidade moral, chamada igreja todos os aderentes". ${ }^{11}$ Para Weber, a religião seria uma ponte, uma via de acesso e correspondência entre o mundo material e espiritual dos agentes. "A religião interessa a Weber na medida em que ela é capaz de formar atitudes e disposições para aceitar ou rejeitar determinados estilos de vida ou para criar novos" ${ }^{12}$ A atividade religiosa para Weber pode ser percebida da seguinte maneira:

O domínio próprio da atividade religiosa consiste em regular as relações das potências 'sobrenaturais' com os homens, precisa Weber, que permanece muito prudente em sua definição liminar do fenômeno

6 PARKER, Cristian. Religião popular e modernização capitalista: outra lógica na América Latina. Petrópolis: Vozes, 1996. p. 140.

7 PARKER, 1996.

8 MONTERO, 1994.

9 LEMOS, Carolina T. Religião e saúde: (re)significando as dores na vida cotidiana. Rio de Janeiro: Descubra, 2008.

10 CROATTO, José S. As linguagens da experiência religiosa: uma introdução à fenomenologia da religião. São Paulo: Paulinas, 2001. p. 71.

11 DURKHEIM, Émile. As formas Elementares da vida religiosa. Trad. Joaquim Pereira Neto. São Paulo: Paulinas, 1989. p. 59.

12 MARIZ, Cecília L. A sociologia da religião de Max Weber. In: TEIXEIRA, Faustino (Org.). Sociologia da Religião: Enfoques teóricos. 3.ed. Petrópolis: Vozes, 2003. p. 67-93. à p. 74. 
religioso; ele recusa particularmente a se pronunciar sobre a essência do religioso. ${ }^{13}$

Na concepção gramsciana, a religião não é um conjunto ideológico homogêneo, mas concretamente subdividido em outras religiões. Para Gramsci, "toda religião principalmente a católica, é na realidade uma multidão de religiões distintas, frequentemente contraditórias". O autor afirma haver nessa religião específica, "um catolicismo de camponeses, um catolicismo dos pequenos burgueses e dos operários urbanos, um catolicismo das mulheres e um catolicismo dos intelectuais, também variado e desconexo". 14 Para fins desta análise, aliamos ao conceito de Durkheim a contribuição de Gramsci, ao destacar a possibilidade de heterogeneidade de concepções e de práticas religiosas no interior de uma mesma religião.

Outro aspecto epistemológico perpassa pelos marcos legais da ciência da religião, Na concepção de Marques e Rocha, as Ciências da Religião têm como ponto de partida no Brasil quase que simultaneamente a chegada dos portugueses. ${ }^{15}$ Os primeiros jesuítas sistematizaram uma série de elementos que são de Ciências da Religião. Em meados do século XIX, aparecem alguns estudos e também teses defendidas na faculdade de medicina, uma vez que ainda não existia Sociologia. Podemos falar mais especificamente em "Ciências da Religião" com a fundação da USP, através da presença de professores franceses, tais como Lévi-Strauss e Roger Bastide. Mediatizados pela sua prática na área de uma Sociologia da Religião, uma Antropologia da Religião que, aliás, teve muito efeito também na Europa, não só no Brasil. Aí se instaura, de fato, um núcleo de estudos mais específicos em Ciências da Religião. Trazemos à tona a história dos seminários católicos no Brasil, que apresentam indícios de um tratamento mais científico à religião. Outro aspecto a ser ressaltado foi a chegada das religiões evangélicas, sobretudo as de origem norte-americanas, e do protestantismo luterano, que suscitaram abordagens do fenômeno religioso já com traços característicos das Ciências da Religião.

No ano de 1965, surge a ideia da implantação do curso de CR no Brasil na Pontifícia Universidade Católica de São Paulo. A USP tem uma importância muito grande, também, nesse aspecto, pelo fato de ter tido vários professores que deram início às CR no Brasil. Na Unicamp, existia apenas a percepção da necessidade de um estudo mais específico do tema. Um aspecto interessante é que o estudo da religião enquanto ciência começa na pós-graduação e não pela graduação, ficando direcionado o estudo de religião

13 WILlAIME, Jean-Paul. Max Weber. In: HERVIEU-LÉGER, Danièle; WILLAIME, Jean-Paul. (Orgs.). Sociologia e Religião: abordagens clássicas. São Paulo: Idéias \& Letras, 2009. p. 71-123. à p. 83.

14 GRAMSCI, Antonio. Cadernos do Cárcere. Rio de Janeiro: Civilização Brasileira, 2001. v. 1. p. 144.

15 MARQUES, A. C. B.; ROCHA, M. Memórias da fase inicial da Ciência da Religião no Brasil - Entrevistas com Edênio Valle, José J. Queiroz e Antonio G. Mendonça. Revista de Estudos da Religião, p. 192-214, mar. 2007. 
no nível de graduação para a Teologia, ou restrito a uma disciplina de Ciências Sociais, Psicologia ou Antropologia, sendo ela quem aprofundou o fenômeno mais a fundo. ${ }^{16}$

As Ciências da Religião, surgem como área autônoma na CAPES no dia 04 de agosto no ano de 2017. Assim, com a institucionalização da religião como ciência, passou e vem passando por momentos distintos de prerrogativas e impasses. No tocante ao Ensino religioso brasileiro, este aspecto se faz presente com a apresentação dos marcos legais, conforme descritos a seguir.

\section{O Ensino Religioso na educação brasileira e os marcos legais}

O ensino religioso inserido no sistema educacional brasileiro sofreu uma evolução devido a decisões legais e a tensões nos sistemas de educação nas esferas municipais, estaduais e federais. Com efeito, as Constituições do Brasil, as Leis de Diretrizes e Bases da Educação Nacional $(4.024 / 61 ; 5.5692 / 71$ e 9.394/96) e as dicussões no Supremo Tribunal Federal e a terceira e última versão da Base Nacional Comum Currricular (BNCC), além de portarias e decretos, têm acirrado o debate em torno do ensino religioso, com discussões que tencionam desde a discriminação de uma religião sobre as outras até os movimentos que vulnerabilizam a questões de laicidade do Estado.

Dentre as discussãoes, enfatizamos a importância da criação em 1995, no Estado de Santa Catarina, do Fórum Nacional Permanente de Ensino Religios (FONAPER). Conforme Caron, o referido Fórum vem estruturando e sistematizando um papel importante para o Ensino Religioso no contexto da Educação Brasileira. ${ }^{17}$ Ocupou-se com a promulgação da Lei de Diretrizes e Bases n. 9394/96, com a produção do Parâmetro Curricular Nacional do Ensino Religioso (PCNER), dentre outras discussões.

De acordo com Junqueira, a premissa determinante do FONAPER é consubstanciar uma nova concepção de Ensino Religioso, propondo e sistematizando ações conjuntas, através das associações de pesquisadores da área, assim como os programas de pós-graduações. ${ }^{18}$ Enfatizando "informações no campo sociológicofenomenológico, tradições e cultura, teologias, textos sagrados orais e escritos, ethos, ritos, em que o professor seja um educador e não um agente religioso". ${ }^{19}$

Com efeito, as primeiras reflexões acerca dessa temática serão elencadas através dos artigos referendados pelas constituições do Brasil, como afirma o quadro a seguir:

Quadro 01: Artigos sobre o ensino religioso nas Constituições Brasileiras.

16 MARQUES; ROCHA, 2007.

17 CARON, Lurdes. Políticas e Práticas Curriculares: formação de professores de ensino religioso. Tese (Doutorado em Educação) - Programa de Pós-Graduação em Educação, Pontifícia Universidade Católica de São Paulo, São Paulo, 2007.

18 JUNQUEIRA, Sérgio R. A. O processo de escolarização do Ensino Religioso no Brasil. Petrópolis: Vozes, 2002.

19 JUNQUEIRA, 2002, p. 28. 


\begin{tabular}{|c|c|}
\hline Constituição do Brasil & Artigo \\
\hline $\begin{array}{l}\text { 1824: Constituição do } \\
\text { imperador" }\end{array}$ & $\begin{array}{l}\text { Art. } 5^{\circ} \text { : A Religião Católica Apostólica Romana continuará a ser a } \\
\text { religião do Império. Todas as outras Religiões serão permitidas com } \\
\text { seu culto doméstico ou particular, em casas para isso destinadas, } \\
\text { sem forma alguma exterior de templo. }\end{array}$ \\
\hline $\begin{array}{l}\text { 1891: } 1^{\text {a }} \text { Constituição do } \\
\text { Brasil República }\end{array}$ & $\begin{array}{l}\text { Art. 72, Parágrafo } 3^{\mathbf{0}} \text { : Todos os indivíduos e confissões religiosas } \\
\text { podem exercer pública e livremente o seu culto [...] Parágrafo } \mathbf{6}^{\mathbf{0}} \text { : } \\
\text { Será leigo o Ensino Ministrado nos Estabelecimentos públicos. } \\
\text { Nenhum culto ou Igreja gozará de subvenção oficial nem terá } \\
\text { relações de dependência ou aliança com o Governo... }\end{array}$ \\
\hline 1934: Constituição do Brasil & $\begin{array}{l}\text { Art. 153: O ensino religioso será de frequência facultativa e } \\
\text { ministrada de acordo com os princípios da confissão religiosa do } \\
\text { aluno, manifestada pelos pais ou responsáveis e constituirá matéria } \\
\text { dos horários nas escolas públicas primárias, secundárias, } \\
\text { profissionais e normais. }\end{array}$ \\
\hline $\begin{array}{l}\text { 1937: Constituição dos } \\
\text { Estados Unidos do Brasil }\end{array}$ & $\begin{array}{l}\text { Art. 133: O ensino religioso poderá ser contemplado como matéria } \\
\text { do curso ordinário das escolas primárias, normais e secundárias. } \\
\text { Não poderá, porém, constituir objeto de obrigação dos mestres ou } \\
\text { professores nem de frequência compulsória por parte dos alunos. }\end{array}$ \\
\hline $\begin{array}{l}\text { 1946: Constituição dos } \\
\text { Estados Unidos do Brasil }\end{array}$ & $\begin{array}{l}\text { Art. 168, Parágrafo } 5^{\circ} \text { : O ensino religioso constitui disciplina dos } \\
\text { horários das escolas oficiais, e de matrícula facultativa e será } \\
\text { ministrado de acordo com a confissão religiosa do aluno, } \\
\text { manifestada por ele, se for capaz, ou pelo representante legal ou } \\
\text { responsável. }\end{array}$ \\
\hline $\begin{array}{l}\text { 1967: Constituição da } \\
\text { República Federativa do } \\
\text { Brasil }\end{array}$ & $\begin{array}{l}\text { IV: O ensino religioso de matrícula facultativa constituirá disciplina } \\
\text { dos horários normais das escolas oficiais de grau primário e médio } \\
{[\ldots] .}\end{array}$ \\
\hline 1969: Constituição do Brasil & $\begin{array}{l}\text { Emenda Constitucional } \mathrm{n}^{\circ} 1, \mathrm{~V}: \text { O ER de matrícula facultativa } \\
\text { constituirá disciplina dos horários normais das escolas de grau } \\
\text { primário e médio [...]. }\end{array}$ \\
\hline 1988: Constituição do Brasil & $\begin{array}{l}\text { Art. } 210 \text {, Parágrafo } \mathbf{1}^{\mathbf{0}}: \text { O ensino religioso, de matrícula facultativa, } \\
\text { constituirá disciplina dos horários normais das escolas públicas de } \\
\text { ensino fundamental. }\end{array}$ \\
\hline
\end{tabular}

Fonte: Quadro organizado de acordo com textos das Contituições Brasileira.

Tendo por base o quadro acima descrito, fica explícito que de fato houve um período histórico em que uma determinada religião era referência para o estado em detrimento das outras religiões. Como pode ser destacado no trecho do Art. $5^{\circ}$, da Constituição do Imperador em 1824, “a Religião Católica Apostólica Romana continuará a ser a religião do Império". ${ }^{20} \mathrm{Ou}$ seja, nesse dado momento a religião Católica era a referência orientadora tanto para o Estado quanto para a educação.

Essa visão ganha um formato diferenciado a partir da $1^{\mathrm{a}}$ Constituição do Brasil República, quando afirma no seu Art. 72, parágrafo $3^{\circ}$, que "todos os indivíduos e confissões religiosas podem exercer pública e livremente o seu culto". E o Parágrafo $6^{\circ}$

20 BRASIL. Constituição do Imperador do Brasil (1824). Disponível em: <http://www.multirio.rj.gov.br/historia/modulo02/const_1824.html>. Acesso em: 23 jun. 2017 
revela que "será leigo o Ensino Ministrado nos Estabelecimentos públicos" ${ }^{21}$ Isto posto, a escola pública ganha a primeira conotação de laicidade. Vale ressaltar que nas escolas confessionais o ensino religioso católico ocorria de forma legítima, com restrições apenas para as escolas públicas.

Esse tipo de entendimento permanceu até 1934, quando então a Constituição do Brasil tornou facultativo o ensino religioso, conforme reza o Art. 153 daquela constituição quando afirma que "o ensino religioso será de frequência facultativa e ministrado de acordo com os princípios da confissão religiosa do aluno, manifestada pelos pais ou responsáveis" e ainda reitera que "constituirá matéria dos horários nas escolas públicas primárias, secundárias, profissionais e normais". 22

Com o príncípio facultativo, percebe-se que embora a disciplina ensino religioso apareça na matriz curricluar das escolas primárias, secundárias, profissionais e normais, não é destinado a essa disciplina a obrigatoridade em frequentá-la, face ao caráter facultativo descrito anteriormente. Essa orientação sofre uma pequena alteração de redação na Constituição de 1937, como exposto no seu Art. 133: “O ensino religioso poderá ser contemplado como matéria do curso ordinário das escolas primárias, normais e secundárias", ou seja, retira-se das escolas profissionais e normais essa disciplina do currículo. Contudo, como afirma a seguir, mantém o carater facultativo: "Não poderá, porém, constituir objeto de obrigação dos mestres ou professores nem de frequência compulsória por parte dos alunos" ${ }^{23}$

Nas constituições a seguir, de 1946, ${ }^{24} 1967,251969$ e a atual, de 1988, ${ }^{26}$ é mantido o caráter em seus respectivos artigos como seguem descritos:

Art. 168, Parágrafo 5 $5^{\circ}$ O ensino religioso constitui disciplina dos horários das escolas oficiais, e de matrícula facultativa [...];

* IV: O ensino religioso de matrícula facultativa constituirá disciplina dos horários normais das escolas oficiais de grau primário e médio [...].

* Emenda Constitucional no 1 V: O ER de matrícula facultativa constituirá disciplina dos horários normais das escolas de grau primário e médio [...].

* Artigo 210, Parágrafo $1^{\circ}$ : O ensino religioso, de matrícula facultativa, constituirá disciplina dos horários normais das escolas públicas de ensino fundamental.

21 BRASIL. Constituição do Brasil República (1891). Disponível em: <http://www.planalto.gov.br/ccivil_03/constituicao/constituicao91.htm>. Acesso em: 23 mar. 2017.

22 BRASIL. Constituição do Brasil (1934). Disponível em: <http://www.planalto.gov.br/ccivil_03/constituicao/constituicao34.htm>. Acesso em: 23 mar. 2017.

23 BRASIL. Constituição dos Estados Unidos do Brasil (1937). Disponível em: <http://www.planalto.gov.br/ccivil_03/constituicao/constituicao37.htm>. Acesso em: 23 mar. 2017.

24 BRASIL. Constituição dos Estados Unidos do Brasil (1946). Disponível em: <http://www.planalto.gov.br/ccivil_03/constituicao/constituicao46.htm>. Acesso em: 23 mar. 2017.

25 BRASIL. Constituição da República Federativa do Brasil (1967). Disponível em: <http://www.planalto.gov.br/ccivil_03/constituicao/constituicao67.htm>. Acesso em: 23 mar. 2017.

26 BRASIL. Constituição da República Federativa do Brasil (1988). Disponível em: <http://www.planalto.gov.br/ccivil_03/constituicao/constituicao88.htm>. Acesso em: 23 mar. 2017. 
Como foram explicitados nos artigos das Constituições de 1946, 1967, 1969 e 1988, perpetua-se a marca do ensino religioso falcultativo, o qual é narrado pela primeira vez na constituição de 1934. Essa compreensão acerca do ensino regioso ancorada nas Cartas Magnas do Brasil, em diferentes momentos históricos, mobilizou educadores, movimentos religiosos e sociais a participarem de novas discussões acerca desse olhar facultativo.

Com efeito, é oportuno salientar que paralelo às Constituições, aqui elencadas, torna-se oportuno destacar a consonância com os artigos das Leis de Diretrizes e Bases da Educação Nacional (LDB), sobre o ensino religioso no sistema educacional, como veremos a seguir:

Art. 97: O ensino religioso constitui disciplina dos horários das escolas oficiais, é de matrícula facultativa, e será ministrado sem ônus para os poderes públicos, de acordo com a confissão religiosa do aluno, manifestada por ele, se for capaz, ou pelo seu representante legal ou responsável. $\S 1^{\circ}$ A formação de classe para o ensino religioso independe de número mínimo de alunos. $\S 2^{\circ} \mathrm{O}$ registro dos professores de ensino religioso será realizado perante a autoridade religiosa respectiva. ${ }^{27}$

Art. $7^{\circ}$ Parágrafo único. $\mathrm{O}$ ensino religioso, de matrícula facultativa, constituirá disciplina dos horários normais dos estabelecimentos oficiais de $1^{\circ}$ e $2^{\circ}$ graus. ${ }^{28}$

O ensino religioso, de matrícula facultativa, constitui disciplina dos horários normais das escolas públicas de ensino fundamental, sendo oferecido, sem ônus para os cofres públicos, de acordo com as preferências manifestadas pelos alunos ou por seus responsáveis, em caráter: I confessional, de acordo com a opção religiosa do aluno ou do seu responsável, ministrado por professores ou orientadores religiosos preparados e credenciados pelas respectivas igrejas ou entidades religiosas; ou II - interconfessional, resultante de acordo entre as diversas entidades religiosas, que se responsabilizarão pela elaboração do respectivo programa. ${ }^{29}$

Desde a primeira Lei de Diretrizes e Bases da Educação Nacional, a LDB n. 4024/61, a Lei n. 5692/71 e a Lei n. 9394/96 reiteram de forma coerente o caráter facultativo do ensino religioso no sistema educacional brasileiro, conforme indicado nas

27 BRASIL. Ministério da Educação. Lei n. 4.024, de 20 de dezembro de 1961, Estabelece as Diretrizes e Bases da Educação Nacional. Disponível em: <http:/ / www.fiscosoft.com.br>. Acesso em: jan. 2013.

28 BRASIL. Lei n. 5.692, de 11 de agosto de 1971. Fixa diretrizes e bases para o ensino de $1^{0}$ e $2^{0}$ graus, e dá outras providências. Diário oficial [da] República Federativa do Brasil, Poder Legislativo, Brasília, 12 ago. 1971. $\quad$ p. $6377 . \quad$ Disponível em: <http:/ / www6.senado.gov.br/legislaçao/ListaTextoIntegral.action?id=75576>. Acesso em: 23 nov. 2017.

29 BRASIL. Lei n. 9394, de 20 de dezembro de 1996. Estabelece as diretrizes e bases da educação nacional. Diário Oficial [da] República Federativa do Brasil, Poder Legislativo, Brasília, 23 dez. 1996. p. 27833. Disponível em: <http://www6.senado.gov.br/legislaçao/ListaTextoIntegral.action?id=75723>. Acesso em: 23 nov. 2017. 
Constituições anteriormente destacadas. Contudo, a LDB n. 9394/96 destaca o caráter confessional de acordo com a opção religiosa dos estudantes e responsáveis, que deve ser efetivado por docentes e ou orientadores devidamente preparados pelas respectivas igrejas ou entidades para ministrar as aulas no âmbito escolar, assim como interconfessional, que teria como enfoque a interlocução entre diferentes religiões, as quais elencariam um programa de conteúdos religiosos "aceitáveis" entre religiões para ser ministrado no âmbito escolar.

É importante frisar que nos contextos das escolas muitas insatisfações foram relatadas, sobretudo no que concerne à pouca aceitação das religiões oriundas de matrizes africanas, ocorrendo embates entre escolas, professores e responsáveis. Com efeito, no ano em 1997, a Lei n. 9.475/97 elabora a seguinte alteração no Art. 33:

O ensino religioso, de matrícula facultativa, é parte integrante da formação básica do cidadão e constitui disciplina dos horários normais das escolas públicas de ensino fundamental, assegurado o respeito à diversidade cultural religiosa do Brasil, vedadas quaisquer formas de proselitismo. $\S 1^{\circ}$ Os sistemas de ensino regulamentarão os procedimentos para a definição dos conteúdos do ensino religioso e estabelecerão as normas para a habilitação e admissão dos professores. $\S 2^{\circ}$ Os sistemas de ensino ouvirão entidade civil, constituída pelas diferentes denominações religiosas, para a definição dos conteúdos do ensino religioso. 30

Assim, além do caráter facultativo, a nova versão do Art. 33 dado pela Lei n. 9.475/97 indica para o sistema educacional a implementação de regulamentação de procedimentos, com vistas a organizar os conteúdos, que serão ministrados no ensino religioso por professores devidamente preparados, para assumir tal atribuição. Outrossim, ainda reitera a possibilidade de escuta da comunidade civil oriundo de diferentes representatividades religiosas, ampliando dessa forma a possibilidade de diálogo e adequação dessa ação na escola, tendo como princípio assegurar a diversidade religiosa no Brasil.

Destarte, não somente as Constituições Brasileiras, as leis de Diretrizes e Bases da Educação Nacional, como também decretos têm influenciado e norteado avanços e impasses nesse campo do ensino religioso, como pode ser observado no Decreto n. 7.107, o qual promulgou a aprovação pelo Congresso Nacional do Acordo Brasil-Santa Sé assinado em novembro do ano de 2008, quando afirma:

Art. 11: A República Federativa do Brasil, em observância ao direito de liberdade religiosa, da diversidade cultural e da pluralidade confessional do País, respeita a importância do ensino religioso em vista da formação integral da pessoa. $\$ 1^{\circ}$. O ensino religioso, católico e de outras confissões

30 BRASIL. Ministério da Educação. Lei n. 9.475/97, de 22 de julho de 1997. Disponível em: <http://www.planalto.gov.br/ccivil_03/LEIS/19475.htm>. Acesso em: 15 set. 2017. 
religiosas, de matrícula facultativa, constitui disciplina dos horários normais das escolas públicas de ensino fundamental, assegurado o respeito à diversidade cultural religiosa do Brasil, em conformidade com a Constituição e as outras leis vigentes, sem qualquer forma de discriminação. ${ }^{31}$

O Art. 11 apresenta no seu bojo dois argumentos coerentes e ao mesmo tempo contraditórios, pois à medida que traz a relevância do direito de liberdade religiosa, da diversidade e pluralidade confessional, em seguida no primeiro parágrafo destaca o ensino religioso católico, mesmo que depois destaque "outras confissões religiosas", ficando evidenciada a relevância nominal de uma religião sobre as demais, mesmo que cite a posteriori a conformidade do que reza a Constituição Brasileira. Como esperado, a aprovação desse Decreto iniciou novas discussões nas instâncias municipais, estaduais e federais. Mas, é no ano de 2015/2016 que nas discussões sobre os Planos Municipais e Estaduais de Educação, as igrejas e a sociedade civil passaram a trazer a voga o retorno do ensino religioso de forma obrigatória, assim como escolas, universidade defenderam o caráter facultativo do ensino religioso.

Assim, em muitos municípios as decisões foram diferentes do que reza a Constituição do Brasil de 1988, no que concerne ao caráter facultativo e defesa da manifestação de diferentes religiões. Outrossim, as discussões implementadas nos diferentes municípios do território brasileiro, elegeram como prioridade a exclusão das abordagens afrodescendentes pela e na escola.

Em tempo, é importante salientar que a Base Nacional Comum Curricular abriu para contribuições da sociedade civil, assim como acatou encaminhamentos dos planos estaduais de ensino. Mas, na sua terceira e última versão final, a BNCC explicita como nota de rodapé 26 , na página 25 que

A área de Ensino Religioso, que compôs a versão anterior da BNCC, foi excluída da presente versão, em atenção ao disposto na Lei de Diretrizes e Bases da Educação Nacional (LDB). A Lei determina, claramente, que o Ensino Religioso seja oferecido aos alunos do Ensino Fundamental nas escolas públicas em caráter optativo, cabendo aos sistemas de ensino a sua regulamentação e definição de conteúdos (Art. 33, § $1^{\circ}$ ). Portanto, sendo esse tratamento de competência dos Estados e Municípios, aos quais estão ligadas as escolas públicas de Ensino Fundamental, não cabe à União estabelecer base comum para a área, sob pena de interferir indevidamente em assuntos da alçada de outras esferas de governo da Federação. ${ }^{32}$

Como foi exposto na nota anterior da BNCC, a responsabilidade do ensino religioso é excluída desse documento, o qual reconhece o Art. 33 e o primeiro parágrafo da

31 BRASIL. Decreto n. 7.107, 2008.

32 BRASIL. Ministério da Educação. Base Nacional Comum Curricular. Estabelece Base Nacional Comum Curricular e Bases da Educação Nacional. Brasília: MEC, 2017. 
LDB como determinantes para que as escolas públicas municipais e estaduais organizem e procedam encaminhamentos do ensino religioso.

No ano de 2017, novamente volta em cena a discussão sobre o ensino religioso no Brasil e mobiliza toda a sociedade. A Procuradoria-Geral da República (PGR) entra com a Ação Direta de Inconstitucionalidade (ADI) n. 4.439, junto ao Supremo Tribunal Federal (STF), ${ }^{33}$ com o propósito de questionar a constitucionalidade do ensino religioso confessional nas escolas públicas de todo o país, com a finalidade de que seja conferida a interpretação, conforme a Constituição Federal, do dispositivo da Lei n. 9.394/96 (caput e parágrafos $1^{\circ}$ e $2^{\circ}$, do Art. 33) e do acordo firmado entre o Brasil e a Santa Sé (Art. 11, parágrafo $1^{\circ}$ ). Pondo em voga o Decreto n. 7.107, de 2010, assinado pelo ex-presidente Luiz Inácio Lula da Silva, que promulgou o acordo assinado entre o Brasil e o Vaticano em 2008, que, dentre outras coisas, reconhece "o ensino religioso, católico e de outras confissões religiosas como disciplina das escolas públicas de ensino fundamental".

No entanto, a Procuradoria-Geral da República, juntamente com organizações que atuam na defesa ao direito à educação, defende que o ensino confessional na rede pública vai de encontro à laicidade do Estado brasileiro, possibilitando meios para doutrinação e proselitismo religioso dentro das escolas, levando a promoção de uma religião em detrimento das demais pertenças, mesmo sendo estabelecido pela Constituição Federal, no Art. 210, referendando a importância do ensino religioso dentro das escolas públicas brasileiras, seja no modelo não-confessional e ministrado por profissionais da educação ligados à rede pública.

O Supremo Tribunal Federal (STF), no dia 15 de junho de 2015, realizou uma audiência pública para debater o assunto, tendo a participação de representantes de diversas religiões e de órgãos e entidades de classe ligados à educação. Os ministros apresentaram seus posicionamentos e argumentos sobre a pauta. Enfatizamos aqui o posicionamento do Conselho Nacional de Educação do Ministério da Educação em referendar a ADI 44390, proposta pela PGR. Diante do exposto, no dia 31 de setembro de 2017, foi colocada em votação e a mesma não foi aprovada. Afirmou-se que um Estado laico como o Brasil é compatível com um ensino religioso confessional, vinculado a uma ou várias religiões específicas, nas escolas públicas.

\section{Considerações finais}

As reflexões efetivadas até aqui acerca do ensino religioso no sistema educacional brasileiro nos permitiram descrever trechos de marcos legais, os quais determinaram o tom de avanços, impasses e retrocessos, pois a busca pelo respeito da pluralidade de expressão religiosa nos parece distante, quando privilegiamos um ensino em detrimento de outros. Quando nominamos uma religião, tomamos partido sobre as demais.

33 BRASIL. Supremo Tribunal Federal. Disponível em: <http://www.stf.jus.br>. Acesso em: 03 nov. 2017. 
Atualmente, vem se acentuando a discussão sobre o Ensino Religioso na Educação Brasileira. Dado esse ainda estigmatizado por concepções arraigadas do passado. Apesar de já ter percorrido um longo percurso de debates no campo educacional brasileiro, ainda existe uma grande falta de conhecimento no tocante à discussão dessa temática dentro deste contexto.

Não podemos nos esquecer que vivemos em uma sociedade com formação multicultural e essa base precisa ser respeitada. A educação religiosa está com essas compreensões, porque ainda carrega resquícios do passado. Os educadores não aceitam mais o modelo catequético/doutrinal do passado, mas ainda falta uma implementação da proposta de trabalho para o presente, mesmo com todo esforço e debate que o Fórum Nacional Permanente de Ensino Religioso (FONAPER) vem tecendo e implementando no sentido de desconstruir esta concepção e implementar uma nova, que respeite as diversidades culturais e religiosas.

Contudo, sabe-se que o Ensino Religioso na educação brasileira, com todas as suas prerrogativas e impasses, ainda é motivo de muitas discussões e controvérsias e a permanência da disciplina no currículo, acentua ainda mais esta polêmica e referenda toda a tessitura da discussão exposta neste estudo. Sabemos que enfrentar esta temática no momento atual não é algo fácil e sim desafiador. Diante da multiplicidade de olhares referendados através da concepção interdisciplinar, do posicionamento atual assumido pelo Supremo Tribunal Federal, diante desta questão, não temos este estudo como conclusivo e sim, como um ponto de partida que suscita a continuidade do mesmo e levanta o chamado para uma reflexão

\section{Referências}

BRASIL. Constituição da República Federativa do Brasil (1967). Disponível em:

<http://www.planalto.gov.br/ccivil_03/constituicao/constituicao67.htm>. Acesso em: 23 mar. 2017.

. Constituição da República Federativa do Brasil (1988). Disponível em:

<http://www.planalto.gov.br/ccivil_03/constituicao/constituicao88.htm>. Acesso em: 23 mar. 2017.

. Constituição do Brasil (1934). Disponível em:

<http://www.planalto.gov.br/ccivil_03/constituicao/constituicao34.htm>. Acesso em: 23 mar. 2017.

. Constituição do Brasil República (1891). Disponível em:

<http://www.planalto.gov.br/ccivil_03/constituicao/constituicao91.htm>. Acesso em: 23 mar. 2017. 
. Constituição do Imperador do Brasil (1824). Disponível em:

<http://www.multirio.rj.gov.br/historia/modulo02/const_1824.html>. Acesso em: 23 jun. 2017

. Constituição dos Estados Unidos do Brasil (1937). Disponível em:

<http://www.planalto.gov.br/ccivil_03/constituicao/constituicao37.htm>. Acesso em: 23 mar. 2017.

. Constituição dos Estados Unidos do Brasil (1946). Disponível em:

<http://www.planalto.gov.br/ccivil_03/constituicao/constituicao46.htm>. Acesso em: 23 mar. 2017.

. Decreto n. 7.107, 2008.

. Lei n. 5.692, de 11 de agosto de 1971. Fixa diretrizes e bases para o ensino de $1^{0}$ e $2^{0}$ graus, e dá outras providências. Diário oficial [da] República Federativa do Brasil, Poder Legislativo, Brasília, 12 ago. 1971. p. 6377. Disponível em:

<http:/ / www6.senado.gov.br/legislaçao/ListaTextoIntegral.action?id=75576>. Acesso em: 23 nov. 2017.

. Lei n. 9394, de 20 de dezembro de 1996. Estabelece as diretrizes e bases da educação nacional. Diário Oficial [da] República Federativa do Brasil, Poder Legislativo, Brasília, 23 dez. 1996. p. 27833. Disponível em:

<http://www6.senado.gov.br/legislaçao/ListaTextoIntegral.action?id=75723>. Acesso em: 23 nov. 2017.

. Ministério da Educação. Base Nacional Comum Curricular. Estabelece Base Nacional Comum Curricular e Bases da Educação Nacional. Brasília: MEC, 2017.

. Ministério da Educação. Lei n. 4.024, de 20 de dezembro de 1961, Estabelece as Diretrizes e Bases da Educação Nacional. Disponível em: <http:/ /www.fiscosoft.com.br>. Acesso em: jan. 2013.

. Ministério da Educação. Lei n. 9.475/97, de 22 de julho de 1997. Disponível em: <http://www.planalto.gov.br/ccivil_03/LEIS/19475.htm>. Acesso em: 15 set. 2017. 03 nov. 2017.

Supremo Tribunal Federal. Disponível em: <http://www.stf.jus.br>. Acesso em:

CARON, Lurdes. Politicas e Práticas Curriculares: formação de professores de ensino religioso. Tese (Doutorado em Educação) - Programa de Pós-Graduação em Educação, Pontifícia Universidade Católica de São Paulo, São Paulo, 2007.

CROATTO, José S. As linguagens da experiência religiosa: uma introdução à fenomenologia da religião. São Paulo: Paulinas, 2001.

DURKHEIM, Émile. As formas Elementares da vida religiosa. Trad. Joaquim Pereira Neto. São Paulo: Paulinas, 1989.

GRAMSCI, Antonio. Cadernos do Cárcere. Rio de Janeiro: Civilização Brasileira, 2001. v. 1 
HUFF JUNIOR, Arnaldo E. Campo religioso brasileiro e a história do tempo presente. Cadernos CERU, série 2, v. 19, n. 2, dez. 2008.

JUNQUEIRA, Sérgio R. A. O processo de escolarização do Ensino Religioso no Brasil. Petrópolis: Vozes, 2002.

LEMOS, Carolina T. Religião e saúde: (re)significando as dores na vida cotidiana. Rio de Janeiro: Descubra, 2008.

MARIZ, Cecília L. A sociologia da religião de Max Weber. In: TEIXEIRA, Faustino (Org.). Sociologia da Religião: Enfoques teóricos. 3.ed. Petrópolis: Vozes, 2003. p. 67-93.

MARQUES, A. C. B.; ROCHA, M. Memórias da fase inicial da Ciência da Religião no Brasil - Entrevistas com Edênio Valle, José J. Queiroz e Antonio G. Mendonça. Revista de Estudos da Religião, p. 192-214, mar. 2007.

MONTERO, Paula. Magia, racionalidade e sujeitos políticos. 1994. Disponível em: <htttp://www.anpocs.org.br/portal/publicações/rbcs0026/rbcs2606.htm>. Acesso em: jun. 2017.

PARKER, Cristian. Religião popular e modernização capitalista: outra lógica na América Latina. Petrópolis: Vozes, 1996. p. 140.

SANCHIS, Pierre. A religião dos Brasileiros: teoria e sociedade. Belo Horizonte: UFMG, 1999.

WILLAIME, Jean-Paul. Max Weber. In: HERVIEU-LÉGER, Danièle; WILLAIME, JeanPaul. (Orgs.). Sociologia e Religião: abordagens clássicas. São Paulo: Idéias \& Letras, 2009. p. 71-123. 